\begin{tabular}{|c|c|c|}
\hline orts il & \multicolumn{2}{|c|}{ Case Rep Gastroenterol 2014;8:39-43 } \\
\hline Gastroenterology & $\begin{array}{l}\text { DOI: } 10.1159 / 000354970 \\
\text { Published online: January 23, } 2014\end{array}$ & $\begin{array}{l}\text { (c) } 2014 \text { S. Karger AG, Basel } \\
\text { 1662-0631/14/0081-0039\$39.50/0 } \\
\text { www.karger.com/crg }\end{array}$ \\
\hline & \multicolumn{2}{|c|}{$\begin{array}{l}\text { This is an Open Access article licensed under the terms of the Creative Commons } \\
\text { Attribution-NonCommercial } 3.0 \text { Unported license (CC BY-NC) (www.karger.com/OA- } \\
\text { license), applicable to the online version of the article only. Distribution permitted for non- } \\
\text { commercial purposes only. }\end{array}$} \\
\hline
\end{tabular}

\title{
A Simple and Safe Procedure to Repair Rectal Prolapse Perineally Using Stapling Devices
}

\author{
Fumitake Hata $^{a} \quad$ Hidefumi Nishimori $^{a} \quad$ Shinichiro Ikeda ${ }^{a}$ \\ Tomomi Yajima $^{a}$ Akihiko Nishio $^{\mathrm{b}}$ Yuji Ishiyama ${ }^{\mathrm{b}}$ \\ ${ }^{a}$ Department of Surgery, Sapporo Dohto Hospital, and ' Sapporo Ishiyama Hospital, \\ Sapporo, Japan
}

\section{Key Words}

Rectal prolapse $\cdot$ Perineal resection $\cdot$ Stapling device

\begin{abstract}
Rectal prolapses are not life-threatening, however the bleeding and fecal incontinence associated with them significantly erode quality of life and can cause concern among patients' caregivers in nursing homes. Many procedures have been reported that repair rectal prolapses, and the procedure used depends on the severity of the prolapse; however, the treatments are yet to be established. Here we report a simple and safe procedure to repair rectal prolapse perineally using stapling devices. We performed this procedure on 5 patients within a short time. All patients were followed up for over 24 months and none had any recurrences of their rectal prolapses. No complications occurred during the operations and postoperative periods. Most patients who have prolapses are elderly and fragile, so the treatment must be easy, safe, and rapid. While rectal prolapse is not life-threatening, the goal of treatment is to alleviate its symptoms. The procedure we describe is consistent with this concept. We suggest that this procedure, which uses surgical stapling devices, might be a better option for the treatment of complete rectal prolapse. We will continue to surgically correct complete rectal prolapses and investigate the long-term outcomes of the procedure.
\end{abstract}

(c) 2014 S. Karger AG, Basel

\section{Introduction}

Rectal prolapse usually occurs in older patients, particularly females. Although not lifethreatening, rectal prolapses can significantly erode quality of life and can cause concern

Fumitake Hata, MD, PhD

Sapporo Dohto Hospital

3-2, Kita17, Higashi 14, Higashi-ku

Sapporo 065-8555 (Japan)

E-Mail fhata@doto.org 
Hata et al.: A Simple and Safe Procedure to Repair Rectal Prolapse Perineally Using Stapling Devices

among patients' caregivers. Many procedures are reported to repair rectal prolapse, and the procedure used depends on the severity of the prolapse and the status of the patient [1]; however, surgical intervention is the mainstream treatment. In elderly and fragile patients, perineal approaches are preferred; for example, Delorme's procedure, with or without the Thiersch procedure, and the Gant-Miwa procedure are options for mild rectal prolapse, whereas Altemeier's procedure is the treatment of choice for severe rectal prolapse. Abdominal approaches such as rectopexy, resection and fixation and, recently, laparoscopic approaches are popular [2], and are generally applied in younger patients. However, these procedures are time-consuming, they demand advanced surgical techniques, and the recurrence rate is not low.

Here we report a simple procedure that repairs rectal prolapse perineally using stapling devices. This technique is essentially the same as the procedure that we have reported for repairing stoma prolapse [3], and it uses surgical stapling devices to completely and safely resect all of the prolapsed rectal wall within a short time.

\section{Patients and Methods}

This procedure was performed at Sapporo Dohto Hospital between August 2009 and June 2010 on 5 patients with complete rectal prolapses accompanied by edema and erosion (table 1). The rectal prolapses had developed 1-6 months before hospital admission, and all prolapses were diagnosed primarily upon admission. Preoperative evaluation of the patients did not reveal any evidence of severe comorbidities that could compromise the operations performed under general anesthesia.

\section{Surgical Procedure}

The patient is placed in a lithotomy position under general anesthesia. The external rectal prolapse is then completely pulled out and clamped using Babcock clamps. Although preoperative diagnostic imaging will have shown that no intra-abdominal organs are trapped between the prolapsed rectal walls, an additional bimanual examination is conducted to confirm there are no other organs caught between the redundant rectal walls. The prolapse is first cut open at the 12 o'clock position using the GIA $100 \mathrm{~mm}$ reloadable stapler (Covidien, Mansfield, Mass., USA) (fig. 1a). The cut end is placed approximately $10 \mathrm{~mm}$ away from the dentate line, taking care to ensure that the stapler does not fire at the dentate line and back wall of the prolapsed rectum. After firing, a PDS ${ }^{\circledR}$ (Ethicon EndoSurgery, Inc.) suture is placed at the end of the line of staples and used for traction. Next, the opposite side of the prolapsed wall is cut open in the same fashion, and the prolapsed rectum is completely divided like a 'French window' (fig. 1b). Each of the divided tissues are resected transversely at the base using another GIA on both sides (fig. 1c). To prevent postoperative pain, special care must be taken to ensure that the stapler does not fire at the dentate line. Finally, the lines of staples are completely oversewn using 8 PDS ${ }^{\circledR}$ sutures (at the $1,2,4,5,7,8,10$ and 11 o'clock positions) to reinforce them and ensure hemostasis (fig. 1d). The anastomosis falls back into place spontaneously.

\section{Results}

Since 2009, 5 patients with complete rectal prolapses have undergone this procedure that uses stapling devices. The clinical characteristics of these patients are shown in table 1. 
Hata et al.: A Simple and Safe Procedure to Repair Rectal Prolapse Perineally Using Stapling Devices

All patients were female and had an average age of 75.6 years. The rectal prolapses had been present 1-6 months preoperatively, and none of the patients had any other prolapsed pelvic organs. All operations were completed within $45 \mathrm{~min}$ (average $31.8 \mathrm{~min}$ ). The resected colons/rectums were 8.0-13.0 cm long (average $10.8 \mathrm{~cm}$ ). No complications, such as major bleeding or intra-abdominal organ injury, occurred during the operations. Postoperatively, no severe complications such as bleeding, anastomotic stenoses, leakage and/or abdominal abscesses occurred. All patients were followed up for over 24 months and none had any recurrences of their rectal prolapses.

\section{Discussion}

Rectal prolapse usually occurs in older patients, particularly females. Although rectal prolapses are not life-threatening, the bleeding and fecal incontinence associated with them significantly erode quality of life and can cause concern among patients' caregivers in nursing homes. Given that rectal prolapse is associated with aging and its prevalence has risen recently, it appears that rectal prolapse will become a serious problem within Japan's aging population.

The following two types of rectal prolapse can occur: complete prolapse and incomplete prolapse [1]. A complete prolapse is defined as a protrusion of the full-thickness colon/rectal wall, whereas an incomplete prolapse is defined as a protrusion of the rectal wall within the anal canal. The treatment options differ for each condition, and here we describe surgical treatment for the complete rectal prolapse.

Many procedures have been reported that repair rectal prolapses, and the procedure used depends on the severity of the prolapse; however, the treatments are yet to be established [3-7]. In terms of perineal approaches, Delorme's procedure and the Gant-Miwa procedure might be feasible for mild prolapses in the elderly, whereas Altemeier's procedure is the surgical option of choice for severe rectal prolapses [6]. Abdominal approaches such as rectopexy, resection and fixation and, recently, laparoscopic approaches are also widely performed in younger patients. However, these procedures tend to be time-consuming, they demand advanced surgical techniques, and the recurrence rate is not low [2].

We have reported a simple procedure that repairs complete rectal prolapses perineally using stapling devices. This is essentially the same as the procedure we reported for repairing stoma prolapse [3]. The indications for the currently described procedure are (1) complete rectal prolapse, (2) over $5 \mathrm{~cm}$ of prolapse, and (3) the ability to staple the prolapsed colon/rectum. Delorme's and/or the Gant-Miwa procedure should be used when a prolapse is $<5 \mathrm{~cm}$ long and when the colon/rectal wall is markedly swollen, because a stapling device is difficult to apply safely in these situations. We performed this procedure in 5 patients with satisfactory outcomes within a short time. Most patients who have prolapses are elderly and fragile, so the treatment must be easy, safe and rapid. While rectal prolapse is not life-threatening, the goal of treatment is to alleviate its symptoms. The procedure we have described is consistent with this concept.

This technique has previously been described by Scherer et al. [8] and is called perineal stapled prolapse resection (PSP). The functional outcome of PSP during a mid-term follow up has also been reported [9]. PSP was performed safely without any intraoperative complications, and only $6.3 \%$ of patients experienced minor postoperative complications. The median time taken to complete the operation was $30 \mathrm{~min}$ (range 15-65 min). The severe fecal incontinence experienced preoperatively disappeared postoperatively in $90 \%$ of the patients, and none of them reported renewed onset of constipation during the follow-up 
Hata et al.: A Simple and Safe Procedure to Repair Rectal Prolapse Perineally Using Stapling Devices

period [9]. Consequently, our report has reiterated the value of stapled resection for complete rectal prolapse.

We suggest that this procedure, which uses surgical stapling devices, might be a better option for the treatment of complete rectal prolapse. We will continue to surgically correct complete rectal prolapses and investigate the long-term outcomes of the procedure.

\section{Disclosure Statement}

The authors have no conflicts of interest to declare.

\section{References}

1 Shin EJ: Surgical treatment of rectal prolapse. J Korean Soc Coloproctol 2011;27:5-12.

-2 Sajid MS, Siddiqui MRS, Baig MK: Open versus laparoscopic repair of full-thickness rectal prolapse: a re-meta-analysis. Colorectal Dis 2010;12:515-525.

-3 Hata F, Kitagawa S, Nishimori H, Furuhata T, Tsuruma T, Ezoe E, Ishiyama G, Ohno K, Fukui R, Yanai Y, Yasoshima T, Koichi H: A novel, easy, and safe technique to repair a stoma prolapse using a surgical stapling device. Dig Surg 2005;22:306-310.

-4 Bachoo P, Brazzelli M, Grant A: Surgery for complete rectal prolapse in adults. Cochrane Database Syst Rev 2000;2:CD001758.

5 Eu KW, Seow-Choen F: Functional problems in adult rectal prolapse and controversies in surgical treatment. Br J Surg 1997;84:904-911.

6 Ris F, Colin JF, Chilcott M, Remue C, Jamart J, Kartheuser A: Altemeier's procedure for rectal prolapse: analysis of long-term outcome in 60 patients. Colorectal Dis 2012;14:1106-1111.

7 Fleming FJ, Kim MJ, Gunzler D, Messing S, Monson JR, Speranza JR: It's the procedure not the patient: the operative approach is independently associated with an increased risk of complications after rectal prolapse repair. Colorectal Dis 2012;14:362-368.

$\checkmark 8$ Scherer R, Marti L, Hetzer FH: Perineal stapled prolapse resection: a new procedure for external rectal prolapse. Dis Colon Rectum 2008;51:1727-1730.

-9 Hetzer FH, Roushan AH, Wolf K, Beutner U, Borovicka J, Lange J, Marti L: Functional outcome after perineal stapled prolapse resection for external rectal prolapse. BMC Surg 2010;10:9.

Table 1. Patient demographics and outcomes of the procedure to repair rectal prolapses in 5 female patients

\begin{tabular}{lllllllll}
\hline $\begin{array}{l}\text { Pa- } \\
\text { tient } \\
\text { No. }\end{array}$ & $\begin{array}{l}\text { Age, } \\
\text { years }\end{array}$ & $\begin{array}{l}\text { Disease } \\
\text { duration, } \\
\text { months }\end{array}$ & $\begin{array}{l}\text { Other } \\
\text { pelvic organ } \\
\text { prolapse }\end{array}$ & $\begin{array}{l}\text { Time to } \\
\text { complete } \\
\text { procedure, min }\end{array}$ & $\begin{array}{l}\text { Length of } \\
\text { resected colon/ } \\
\text { rectum, cm }\end{array}$ & $\begin{array}{l}\text { Compli- } \\
\text { cations }\end{array}$ & $\begin{array}{l}\text { Recur- } \\
\text { rence }\end{array}$ & $\begin{array}{l}\text { Follow- } \\
\text { up, } \\
\text { months }\end{array}$ \\
\hline 1 & 70 & 1 & - & 42 & 11.0 & - & - & 41 \\
2 & 56 & 2 & - & 44 & 13.0 & - & - & 38 \\
3 & 86 & 2 & - & 26 & 10.0 & - & - & 32 \\
4 & 86 & 6 & - & 22 & 12.0 & - & - & 32 \\
5 & 80 & 2 & - & 25 & 8.0 & - & - & 31 \\
\hline
\end{tabular}


Hata et al.: A Simple and Safe Procedure to Repair Rectal Prolapse Perineally Using Stapling Devices
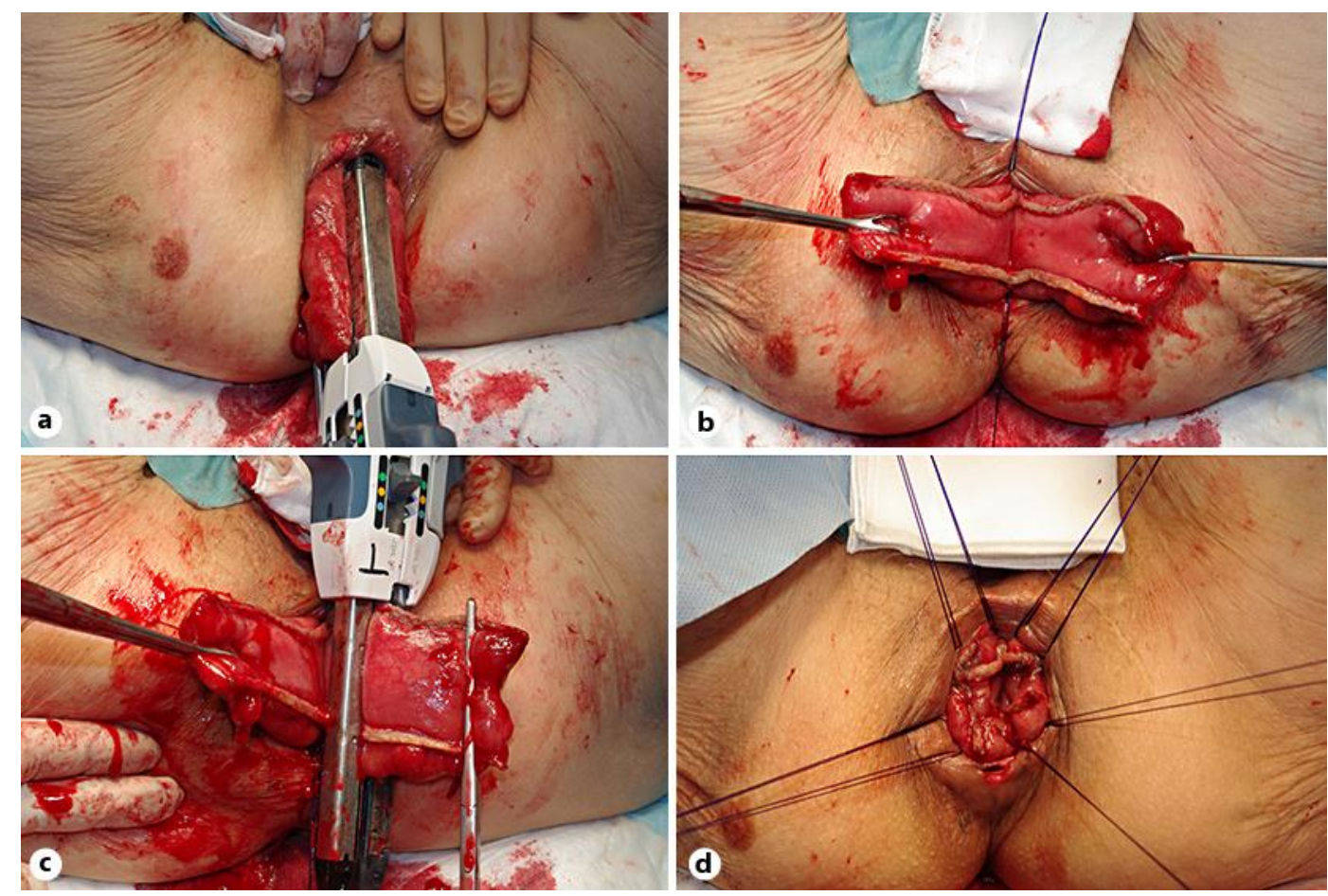

Fig. 1. a This patient's rectal wall protruded approximately $10 \mathrm{~cm}$ from the anal verge with marked redness, swelling and erosion, which could not be alleviated manually. A GIA was introduced through the opening of the prolapsed rectum at the 12 o'clock position and fired. The prolapsed rectum was transected on the opposite side using the same stapler. $\mathbf{b}$ The prolapsed rectum was then completely divided like a 'French window'. c Finally, the divided tissue was stapled transversely at the bottom and fired upon. Then the prolapsed rectum was completely resected. $\mathbf{d}$ The lines of staples were completely oversewn with 8 PDS $^{\circledR}$ sutures (at the 1, 2, 4, 5, 7, 8, 10 and 11 o'clock positions) to reinforce them and ensure hemostasis. The anastomosis fell back into position spontaneously. 